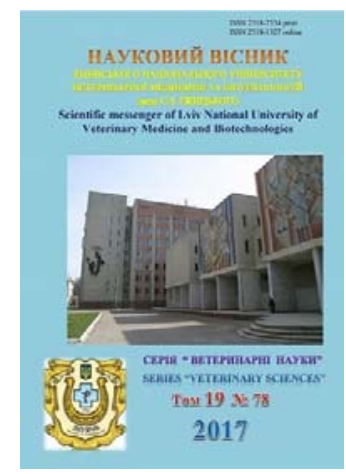

Науковий вісник Львівського національного університету ветеринарної медицини та біотехнологій імені С.З. Гжицького

Scientific Messenger of Lviv National University of Veterinary Medicine and Biotechnologies

doi:10.15421/nvlvet7805

ISSN 2518-7554 print

ISSN 2518-1327 online

$\underline{\text { http://nvlvet.com.ua/ }}$

УДК 636.09:615.273:546.72

\title{
Сучасні тенденції на вітчизняному ринку ферумвмісних препаратів для тварин
}

\author{
I.M. Деркач \\ irina1215@ukr.net \\ Національний університет біоресурсів і природокористування Украӥни, \\ вул. Полковника Потсхіна, 16, м. Київ, 03041, Україна
}

У статті наведено аналіз вітчизняного ринку ветеринарних препаратів Феруму. Встановлено, що нині він представлений 13-ма лікарськими засобами групи QB03A Протианемічні засоби. Препарати заліза, згідно з АTC-vеt класифікацією. Асортимент на 38\% забезпечений фармачевтичним товаром українських виробників: «O.L.KAR-Агро3ооВет-Сервіс», ПП фірма «Фарматон», ТОВ «БРОВАФАРМА», ТзОВ «Дослідно-експериментальне виробництво інституту епізоотологї», ПП «Біофарм», ТОВ «Ветсинтез». Імпортну продукиію (62\%) представляють Фармакосмос А/С (Королівство Данія), МЕРІАЛ, КООФАВЕТ С.А.С. (Франиія), Вуген Б\&Г Ко., Лто (Південна Корея), Біовет Пулави Сп. з о.о. (Польща), Інтерхемі веркен "Де Аделаар» Есті АС (Естонія), Біовета, а.с. (Чеська Республіка). У складі сучасних препаратів використано декстрановий комплекс гідроксиду феруму (III). 46\% лікарських засобів містять його комбіначії з іншими активнодіючими речовинами. У 4-х препаратах, а саме Інтрафер-100 В12, Iнтрафер-200-В12, Феровіта-200, Ферровет+В12, окрім нього $\epsilon$ ціанокобаламін. Вітаміни інших груп, макро- та микроелементи, інактивована нормальна сироватка крові свиней входять до складу ГАФЕРВІТу (Біовета, а.с., Чеська Республіка) та Суіферовіту (Біовет Пулави Сп. з о.о., Польща). 3 вищезазначених тільки ФЕРРОВЕТ + В12 є препаратом вітчизняного виробництва (ТОВ «Ветсинтез»).

Ключові слова: фармачевтичний ринок, виробник, продукиія, товар, імпорт, ветеринарний препарат, Ферум, декстран.

\section{Современные тенденции на отечественном рынке ферумсодержащих препаратов для животных}

\author{
И.М. Деркач \\ irina1215@ukr.net
}

Национальный университет биоресурсов и природопользования Украинь,

ул. Полковника Потехина 16, Киев, 03041, Украина

\begin{abstract}
В статье приведен анализ отечественного рынка ветеринарных препаратов ферума. Установлено, что в настоящее время он представлен 13 лекарственными средствами группь QB03A Противоанемические средства. Препарать железа, согласно АТС-vеt классификачии. Ассортимент на 38\% обеспечен фармацевтическим товаром украинских производителей: «O.L.KAR- АгроЗооВет-сервис», ПП фирма «Фарматон», ООО «БРОВАФАРМА», ТзОВ «Опытно-экспериментальное производство института эпизоотологии», ПП «Биофарм», ООО «Ветсинтез». Импортную продукиию (62\%) представляют Фармакосмос А/с (Королевство Дания), МЕРИАЛ, КООФАВЕТ С.А.С. (Франция), Вуген Б\&Г Ко., Лтд (Южная Корея), Биовет Пулавы Сп. из о.о. (Польша), Интерхеми веркен «Где Аделаар» Ести АС (Эстония), Биовета, а.с. (Чешская Республика). В составе современных препаратов использован декстрановый комплекс гидроксида ферума (III). 46\% лекарственных средств содержат его комбиначии с другими активно действующими веществами. В 4-х препаратах, а именно Інтрафер-100 В12, Інтрафер-200-В12, Феровита-200, Ферровет В12, кроме него, есть иианокобаламин. Витамины других групп, макро- и микроэлементы, инактивированная нормальная сыворотка крови свиней входят в состав ГАФЕРВЕТа
\end{abstract}

Citation:

Derkach, I. (2017). Modern trends of the Ukrainian market of ferumcontaining products for animals. Scientific Messenger LNUVMB, 19(78), 23-25. 
(Биовета, а.с., Чешская Республика) и Суиферовита (Биовет Пулавы Сп. из о.о., Польша). Из вышеупомянутых только ФЕРРОВЕТ В12 является препаратом отечественного производства (ООО «Ветсинтез»).

Ключевые слова: фармацевтический рынок, производитель, продукция, товар, импорт, ветеринарный препарат, ферум.

\title{
Modern trends of the Ukrainian market of ferumcontaining products for animals
}

\author{
I. Derkach \\ irina1215@ukr.net
}

National University of life and environmental sciences of Ukraine,

Polkovnyka Potekhyna Str., 16, Kyiv, 03041, Ukraine

The article presents an analysis of the domestic market of veterinary preparations of Ferum. It is established that nowadays it is represented by 13 drugs of the following group: QV03A Antianemic agents. Preparations of iron, according to ATS-vet classification. Assortment of $38 \%$ is provided by pharmaceutical goods of Ukrainian producers: «O.L.KAR-AgroZoOvetService», PP Farmaton, LLC «BROVAFARMA», Ltd. "Research and experimental production Institute of Epizootology», PP "BIOFARM», LLC «Vetsintez». Imported products (62\%) are presented by Pharmacosmos A/S (Kingdom Denmark), MERIEL, KOOFAVET C.A.C. (France), Wagen B \& G Co., Ltd. (Southern Korea), Bovet Pulawi Cp. with oh (Poland), Interchemy Werken «De Adelaar» Esti AS (Estonia), Biowet, a.s. (Czech Republic).

In the composition of modern drugs, the dextran complex of ferric hydroxide (III) is used. Its combination with other active substances is included into 46\% of medicines. Preparations, such as Intrafer-100 B12, Intrafer-200-B12, Ferovita-200, Ferrovet $+B 12$ also contain cyanocobalamin.Vitamins of other groups, macro- and micronutrients, inactivated normal pig blood serum are contained in GAFFERWIT (Biowet, Czech Republic) and Soiferovit (Bilovet Pulawi, Poland). Among the above-mentioned drugs only FERROVET + B12 is produced in Ukraine (LLC «Vetsintez»).

Key words: pharmaceutical market, producer, products, goods, import, veterinary medicine, ferum, dextran.

\section{Вступ}

Ферум - один із найважливіших мікроелементів, необхідний для процесів росту, дихання, кровотворення, імунобіологічних та окисно-відновних реакцій в організмі. Основна його біологічна роль - участь в еритропоезі, під час якого він використовується для синтезу гемоглобіну. Нестача, як і надмір, заліза негативно впливає на стан здоров'я як людей, так і тварин (Bonkovsky and Herbert, 1991; Andreeva and Serpkov, 2002; Killip and Bennett, 2007; Sidorkin et al., 2007; Zharov and Zharov, 2012).

За залізодефіцитних анемій особливо ефективними є колоїдні розчини гідроокисів феруму внизькомолекулярних полімерах глюкози - так звані залізодекстрани. Найчастіше у ветеринарній медицині їх застосовують для створення у печінці поросят запасів заліза в період внутрішньоутробного розвитку, у перші дні після народження поросятам і телятам, а також хутровим звірам за наявності у їх раціоні риби (Kaniuka and Falterberh-Blank, 2006).

Сьогодні ринок ветеринарних препаратів України достатньою мірою забезпечено ефективними антианемічними засобами. Для зниження залежності нашої країни від закордонного виробника українські вчені працюють над розробкою вітчизняних протианемічних лікарських засобів (Melnychenko et al., 2014).

\section{Матеріал і методи досліджень}

Метою роботи було вивчення шляхом аналізу літературних та інших інформаційних джерел сучасних тенденцій національного ринку ветеринарних препаратів феруму, зареєстрованих в Україні.

\section{Результати та їх обговорення}

У доступних нам інформаційних джерелах до переліку зареєстрованих ветеринарних препаратів, кормових добавок, готових кормів та преміксів не внесено зміни у період 2016-1017 pp. (Zareiestrovani veterynarni preparaty, kormovi dobavky, hotovi kormy ta premiksy). Так, у 2016 році завершився термін реєстрації 4-х: Реаферону-75 (ПрАТ «РЕАГЕНТ», Україна), Біоферону (ТОВ АТ «Біофарм», Україна), Фероселеніту (ВК «Круг», Україна). Феровіту (Вуген Б\&Г Ко., Лтд, Південна Корея).

У 2017 р. на вітчизняному ринку лікарських засобів зареєстрованими є 13 препаратів феруму (див. рис.).

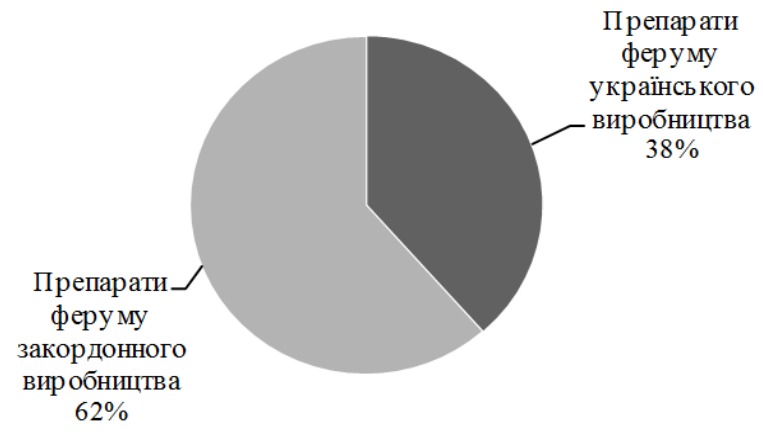

Рис. Вітчизняний ринок ферумвмісних препаратів для тварин

3 даних рисунка випливає, що сучасний ринок препаратів феруму в Україні на $38 \%$ забезпечено вітчизняними виробниками. Вони пропонують таку фармацевтичну продукцію: Феролайф («O.L.KARАгроЗооВет-Сервіс»), Ферофарм (ПП фірма «Фарматон»), Броваферан-100 (ТОВ «БРОВАФАРМА»), Феродев (ТзОВ «Дослідно-експериментальне вироб- 
ництво інституту епізоотології», ПП «Біофарм»), ФЕРРОВЕТ $+B 12$ (ТОВ «Ветсинтез»).

Імпортну продукцію по одному препарату представляють Фармакосмос A/C (Королівство Данія), МЕРІАЛ, КООФАВЕТ С.А.С. (Франція), Вуген Б\&Г Ко., Лтд (Південна Корея), Біовет Пулави Сп. 3 о.о. (Польща). По два препарати пропонують: Інтерхемі веркен «Де Аделаар» Есті АС (Естонія) - Інтрафер200 B12, Iнтрафер-100 B12; Біовета, а.с. (Чеська Республіка) - ФЕРРІБІОН 10\%, ГАФЕРВІТ.

У складі всіх сучасних препаратів використано декстрановий комплекс гідроксиду феруму (III), 46\% лікарських засобів містять його комбінації з іншими речовинами. У 4-х препаратах, а саме Iнтрафер-100 B12, Iнтрафер-200 B12, Феровіта 200, Ферровет $+B 12$, окрім нього, $\epsilon$ ціанокобаламін.

Варто виділити ще 2 антианемічні засоби. Так, до складу ГАФЕРВІТ (Біовета, а.с., Чеська Республіка) входять: феруму (III) декстрановий комплекс, вітамін В1, вітамін В2, вітамін В6, вітамін РР, кальцію пантотенат, купруму хлорид, кобальту хлорид, інактивована нормальна сироватка крові свиней.

Cуіферовіт (Біовет Пулави Сп. 3 о.о., Польща) містить активнодіючі речовини: імуноглобулін нормальної сироватки крові свиней, феруму декстран, тіаміну гідрохлорид, рибофлавін, піридоксину гідрохлорид, нікотинамід, кальцію пантотенат, купруму хлорид, кобальту хлорид безводний.

Вищевказані лікарські засоби, у складі яких є ферумдекстрановий комплекс у комбінації 3 іншими речовинами, становлять 46\% на вітчизняному фармацевтичному ринку препаратів феруму; це імпортний товар та лише один виробляється в Україні, а саме ФЕРРОВЕT+B12 (ТОВ «Ветсинтез»).

Лікарські засоби згідно з АТC-vet класифікацією мають код QB03A Протианемічні засоби. Препарати заліза. Ферумвмісні лікарські засоби проявляють протианемічну дію завдяки наявності малотоксичного та водорозчинного залізодекстранового комплексу. Вони стимулюють роботу кровотворної системи та синтез гемоглобіну, що призводить до збільшення кількості еритроцитів. Результатом активізації тканинних обмінних процесів $€$ підвищення інтенсивності росту тварин, зростання їх резистентності до дії негативних факторів довкілля. Солі купруму, кобальту та вітаміни групи В діють синергічно, посилюючи вплив феруму, регулюють обмін речовин і компенсують нестачу цих елементів у кормах.

Після внутрішньом'язової ін'єкції декстран феруму швидко всмоктується з місця ін'єкції через капілярні та лімфатичні судини. Із плазми крові видаляється клітинами ретикулоендотеліальної системи, в яких розділяється на залізо та декстран. Ферум зв'язується 3 протеїнами, утворюючи комплекси гемосидерин, феритин та трансферин. Вітамін В12 необхідний для синтезу ДНК.

До 60\% декстрану заліза всмоктується через 3 доби після введення, до 90\% - протягом 1-3 тижнів. Період напіввиведення феруму з плазми крові становить 5 год; незначні кількості виділяються із сечею. Декстран метаболізується та виводиться 3 організму через нирки.
Показаннями до застосування ферумвмісних засобів $є$ лікування та профілактика анемій, набрякової хвороби, гіпо- та агаммаглобулінемій поросят і свиней, а також хвороб, пов'язаних з періодом відлучення від свиноматок. Серед протипоказань до таких препаратів зазначається: не застосовувати тваринам із недостатністю вітаміну Е та/або селену, за наявності діарей, у комбінації з тетрациклінами та у разі гіперчутливості до активної речовини.

Серед побічних ефектів можливі реакція гіперчутливості, короткочасна зміна кольору та затвердіння у місці ін'єкції. Дуже рідко поросята помирають після парентерального введення декстрану заліза, що пов'язують з генетичними факторами або дефіцитом вітаміну Е та/або селену.

\section{Висновки}

Вітчизняний ринок ветеринарних препаратів феруму на $38 \%$ забезпечений фармацевтичним товаром шести українських виробників, серед яких лише один використовує комбінацію ферумдекстранового комплексу з іншими речовинами (ФЕРРОВЕТ + В12, ТОВ «Ветсинтез»). Переважна більшість імпортної продукції представлена «Де Аделаар» Есті АС (Естонія) та Біоветою, а.с. (Чеська Республіка) - по два ферумвмісні препарати.

Перспективи подальших досліджень. У перспективі подальших досліджень вбачаємо порівняльне вивчення ефективності ферумвмісних препаратів закордонного та вітчизняного виробництва.

\section{Бібліографічні посилання}

Andreeva, A., Serpkov, A. (2002). Kak predotvratit' alimentarnuju anemiju porosjat. Zhivotnovodstva. 2, 87 (in Russian).

Zharov, A.V., Zharov, Ju.P. (2012). Patologija obmena veshhestv u vysokoproduktivnyh zhivotnyh. Veterinarija. 9, 46-50 (in Russian).

Sidorkin, V., Gavrish, V., Egunova, A., Ubiraev, V. (2007). Bolezni svinej. M.: OOO «Akvarium - print» (in Russian).

Bonkovsky, S., Herbert, L. (1991). Iron and the Liver. Amer. J. Med. Sci. 301(1), 32-43 (in Russian).

Killip, S., Bennett, M. (2007). Iron Deficiency Anemia. American Family Physician. 75(5), 671-678.

Kaniuka, O.I., Falterberh-Blank, V.R. (2006). Klinichna veterynarna farmakolohiia. Odesa: Astroprynt, 121122 (in Ukrainian).

Melnychenko, O.M., Vered, P.I., Kharchyshyn, V.M. (2014). Profilaktyka alimentarnoi anemii porosiat vitchyznianymy ta importnymy antyanemichnymy preparatamy. Tekhnolohiia vyrobnytstva i pererobky produktsii tvarynnytstva. 2, 10-12 (in Ukrainian).

Zareiestrovani veterynarni preparaty, kormovi dobavky, hotovi kormy ta premiksy [Elektronnyi resurs]. Rezhym dostupu: http://vet.gov.ua/node/888 (in Ukrainian). 